Volume 13

Issue 2 Rethinking Genocide, Mass Atrocities,

and Political Violence in Africa: New Directions,

Article 4

New Inquiries, and Global Perspectives

6-2019

\title{
Rethinking Genocide, Mass Atrocities, and Political Violence in Africa
}

Laura Collins

Follow this and additional works at: https://digitalcommons.usf.edu/gsp

\section{Recommended Citation}

Collins, Laura (2019) "Rethinking Genocide, Mass Atrocities, and Political Violence in Africa," Genocide Studies and Prevention: An International Journal: Vol. 13: Iss. 2: 2-13.

DOI:

https://doi.org/10.5038/1911-9933.13.2.1707

Available at: https://digitalcommons.usf.edu/gsp/vol13/iss2/4

This Front Matter is brought to you for free and open access by the Open Access Journals at Digital Commons @ University of South Florida. It has been accepted for inclusion in Genocide Studies and Prevention: An International Journal by an authorized editor of Digital Commons @ University of South Florida. For more information, please contact digitalcommons@usf.edu. 


\section{Guest Editorial: Rethinking Genocide, Mass Atrocities, and Political Violence in Africa}

Are conflicts dynamic processes? Though seemingly answered with a simple yes, the tendency at times to analyze and thereafter market complex conflict processes based on discrete categories of violence exposes a shortcoming in current analyses of conflict throughout the African continent. This not only suggests the need to problematize the very analytical frames employed to understand conflicts and how we respond to violence, but also interrogate why certain frames are applied selectively despite cross case similarities or why particular violence metanarratives are superimposed on conflict dynamics with little regard for how subnational processes may "map onto" or undermine macro conflict dynamics over time. ${ }^{1}$ While conflict framing is critical for building and developing theory as well as informing conflict prevention and resolution strategies, it has the potential to narrow our vision, obscuring the evolving nature of conflicts, and impeding peacebuilding efforts. Concealing pertinent factors driving conflict may not be the only unintended consequence of conflict framing. Perhaps more pressingly, the way in which conflict and violence are framed, and the approaches taken, thereafter, may function to facilitate violence escalation rather than mitigation. This poses a critical challenge to scholars and practitioners studying political violence.

In spite of an initial downward trend in political violence in the form of internal armed conflict to capture control of the state and replace incumbent governments, and an increase in varying levels of democratic governance on the continent throughout the beginning of the new millennium, ${ }^{2}$ notable challenges persist as others have increased in significance. Of note is not only the shift over the past ten years of this downward trend in violent armed conflict in the opposite direction, but how this shift has been coupled with a revival and evolution of violence in African states from Central African Republic to Mali to Libya, and elsewhere with links to past occurrences of instability and insurgency. ${ }^{3}$ Manifestations of political violence in the form of electoral violence, riots, repression, and various forms of lethal economic predation remain. What cannot be overlooked when discussing the dynamics of violence in each of these cases however, as in many others, is the matter of varying external and militarized forms of intervention in each of their histories (on Libya, see Kuperman, this issue). Nor can we overlook the ambiguity that can exist between peace and wartime contexts within the same country case. As such, it is not only important to consider the socio-economic and political processes fostering a resurgence and evolution of violence, but to do this in a way that is neither blind to nor blinded by history. ${ }^{4}$ (See Purdeková, this issue). Relatedly, the continued presence, yet increasingly diverse conglomeration of violent nonstate actors on the continent from Nigeria, to Somalia, to DRC, and elsewhere has been connected to an upward trend in transborder conflict and violence. ${ }^{5}$ While these sub-state armed entities move cross border from statal peripheral areas for a variety of reasons from securing material resources from financing to

\footnotetext{
${ }^{1}$ Stathis Kalyvas, The Logic of Violence in Civil War (New York: Cambridge University Press, 2006), 6, 374.

${ }^{2}$ For a more in-depth discussion of trends during the post-colonial period through 2012, see, Scott Straus, "Wars Do End! Changing Patterns of Political Violence in Sub-Saharan Africa," African Affairs 111, no. 443 (2012), 179-201. DOI: 10.1093/afratf/ads015; for an in-depth discussion of trends during the period from 2010 onwards, see, Paul D. Williams, "Continuity and Change in War and Conflict in Africa," Prism 6, no. 4 (2017), 32-45, accessed December 12, 2018, https://www.jstor.org/stable/10.2307/26470480.

${ }^{3}$ Williams, Continuity and Change, 32-45; Christian von Soest and Alexander De Juan, "Dealing with New Security Threats in Africa," GIGI Focus Afrika 2 (2018), 2, Hamburg: GIGA German Institute of Global Area Studies - LeibnizInstitute für Globale und Regionale Studien, Institute für Afrika-Studien, accessed December 12, 2018, https://www. ssoar.info/ssoar/bitstream/handle/document/57825/ssoar-2018-soest et al-Dealing with New Security Threats.pd f?sequence=1\&isAllowed=y\&lnkname=ssoar-2018-soest et al-Dealing with New Security Threats.pdf; Barbara F. Walter, “Why Bad Governance Leads to Repeat Civil War," Journal of Conflict Resolution 59, no. 7 (2015), 1242-1272. DOI: $10.1177 / 0022002714528006$

${ }^{4}$ See, Tatiana Carayannis and Louisa Lombard, eds., Making Sense of the Central African Republic (London: Zed Books, 2015). Carayannis and Lombard make the point that the 'crisis' moniker given to the more recent resurgence in violence in the Central African Republic at the end of 2012 was misleading. Rather than an aberration, the violence was and continues to be connected to deeper, more persistent structural and historical dynamics.

${ }^{5}$ Von Soest \& De Juan, Dealing with New Security, 3-4; Straus, Wars Do End, 190-191.
} 
support, what is apparent is the devastating effects on civilians. From the effects of transborder violence more generally and direct targeting more specifically, militarized statal responses to certain non-state agents have also had devastating and lasting consequences (see Loadenthal, this issue). While identity variables from ethnicity to religion continue to be relevant in analyses of conflict and violence, with some pointing to the increased importance of religion in conjunction with the activities of certain non-state armed actors, ${ }^{6}$ others point to the increasing significance of violence throughout the continent emanating from farmer-pastoralists dynamics. ${ }^{7}$ Lastly, from Algeria to Sudan most recently, the African continent as a whole is witnessing an increasing rate of nonviolent uprisings, successfully deposing of entrenched authoritarian regimes. As scholars of civil resistance have suggested and, particularly in reference to Sudan, where international indictments for mass violence and arrest warrants failed, mass mobilization triumphed in unseating a brutal leader. ${ }^{8}$

Yet, it is against this backdrop of some of these emerging trends across the continent that the term "genocide" has also been employed to characterize violence or the risk of violence in Sudan, South Sudan, Central African Republic, Nigeria, Democratic Republic of Congo, and Burundi. In addition to considering the applicability of the genocide frame, we must also ask if the application of the word genocide to understand political violence has been more of a help or a hindrance to conflict resolution and peacebuilding efforts in these countries? Has the word genocide overemphasized the role of identity and, particularly ethnicity and religion in conflict, concealing the role of powerful international actors or structural drivers of conflict in each of these cases? Has the word genocide concealed conflicts over governance, and access to economic opportunities and resources? Does the focus on sovereign actors obscure the roles played by local, non-state, and transnational actors in the production of violence?

Relatedly, terms such as atrocity crimes and the responsibility to protect were developed purposefully over the last decade to downplay the implications of terms such as genocide and crimes against humanity, and shift international political discourse from one of "prevention as intervention" to a positive discourse of "prevention as a responsibility." How have these concepts shifted our frames of reference, in terms of practice, politics, and scholarship? And what has been the impact, if any, of this shift? Has the Rule of Law, Responsibility to Protect, and Early Warning and Early Prevention movements helped foster peace, or have they deflected blame from powerful global actors to local actors? Elsewhere the labels of "extremism" and "terrorism" have been applied by international observers and national governments in Nigeria, Libya, Tunisia, Uganda, Somalia, Mali, and elsewhere. Have these concepts served to facilitate or hinder peace efforts in these countries? Have the descriptors of "violent extremism" and "terrorism" created a false narrative that these dynamics are characteristics of African conflicts and their conflict actors in particular? Have these terms focused our analytical gaze on religion or ideology, while concealing other important political and economic aspects of political struggles and conflict? In other words, does labeling an actor a "terrorist" or extremist" depoliticize their actions and reify a category that makes conflict resolution more difficult.

\section{Genocide, (Political) Violence, and Conflict}

Genocide and conflict, or more specifically varying forms of political violence have been increasingly brought into conversation theoretically. Scholars have not merely sought to understand the differences, but also the nexus between these forms of large-scale violence. To that effect, studies have examined the occurrence of genocide against the backdrop of war and developed cross-case, multi-leveled comparisons of genocide and likely genocidal violence to expose critical mechanisms

\footnotetext{
${ }^{6}$ William, Continuity and Change, 40.

${ }^{7}$ Straus, Wars do End, 192-195; Juliana Nnoko-Mewanu, "Farmer-Herder Conflicts on the Rise in Africa," Human Rights Watch, August 6, 2018, accessed April 12, 2019, https://www.hrw.org/news/2018/08/06/farmer-herder-conflicts-riseafrica; "Farmer-pastoralist conflicts cause more deaths than Boko Haram," The Nordic Africa Institute, June 26, 2017, accessed April 12, 2019, https://nai.uu.se/news/articles/2017/06/26/113908/index.xml.

${ }^{8}$ Zoe Marks, et al, “How Protest Movements Are Succeeding Where Even Global Arrest Warrants Can't," Foreign Affairs, April 25, 2019, accessed April 26, 2019, https://www.foreignaffairs.com/articles/africa/2019-04-25/people-power-risingafrica.
} 
of restraint and escalation. Elsewhere, examinations of multi-party conflicts have pointed to a connection between negotiating peace in the context of multi-party civil wars and escalation toward genocide as mediated by a large number of negotiating veto players. ${ }^{9}$ Notwithstanding these theoretical advancements in our understanding of the logic of contemporary genocidal violence, in many ways, the concept of genocide does not provide a helpful analytical frame for understanding the dynamics of violent conflict in African contexts. Part of the reason for this is the term is often used in highly politicized discourses around issues of naming and responding to political violence. And, when applied, genocide determinations can serve to shape conflict analyses and what is understood to be evolving on the ground rather than the reverse. That is -still embedded within the concept of genocide, then, is a logic predetermining our understanding of the genesis and motivation for violence, the protagonists and their (absolute) agency (or lack thereof), and the ultimate trajectory and necessary means of action.

Of note in this regard is Dirk Moses' work that speaks of a continued oversimplification in how mass violence is conceptualized and analyzed. ${ }^{10}$ Citing the interconnected intellectual development of Holocaust studies and Genocide Studies respectively, Moses points to the way in which the concept of genocide was gradually reframed in the image of the Holocaust as a strict policy of mass killing enacted by a totalitarian or authoritarian state and propelled exclusively by an exclusionary (identity centric) ideology. ${ }^{11}$ By extension, non-genocidal occurrences of extreme violence are understood more conventionally as inherently political, fought over tangible concerns (access to land, resources, power), and violence is more restrained than absolute. ${ }^{12}$ Conceptually framed as such, genocidal violence is at once decontextualized and a-political. ${ }^{13}$ Moreover, when the motivating logic of genocidal violence is anchored within specific regime types and their associated ideologies, as Irvin-Erickson observes, this serves to anchor the occurrence of genocide exclusively (and erroneously) "within unfamiliar non-western, non-liberal, or non-democratic ideologies." ${ }^{14}$ The application of this genocide frame to the violence in Darfur, Sudan in the 2000s served to shape analyses toward a singular focus on the state, obscuring the micropolitics and dynamics of the genocidal violence. As such, policy and advocacy discussions over the violence in Darfur, Moses writes, "were preoccupied with the Islamism of the Khartoum regime rather than the logic of counter-insurgency and civil war, a potential in all societies."15

It is from here that the nexus between violence and issues of actor and agency are influenced by these assumptions embedded in this framing of genocide. More specifically, homogenized portrayals

\footnotetext{
${ }^{9}$ For a general conversation over the need to bring genocide into conversation with the study of political violence, see, Ernesto Verdeja, "On Situating the Study of Genocide within Political Violence," Genocide Studies and Prevention 7, no. 1 (2012), 81-88. DOI: 10.3138/gsp.7.1.81; on mechanisms of restraint against and escalation toward genocide, see, Scott Straus, Making and Unmaking Nations: War, Leadership, and Genocide in Modern Africa (New York: Cornell University Press, 2015); on issues of war and genocide, see, Martin Shaw, Genocide and International Relations: Changing Patterns in the Upheavals of the Late Modern World (Cambridge, UK: Cambridge University Press, 2013); Martin Shaw, What is Genocide? (Cambridge, UK: Polity, 2007); on issues of civil war, negotiating peace, and escalation toward genocide, see, David E. Cunningham, Barriers to Peace in Civil Wars (Cambridge, UK: Cambridge University Press, 2011).

${ }^{10}$ Dirk A. Moses, "Paranoia and Partisanship: Genocide Studies, Holocaust Historiography, and the 'Apocalyptic conjecture'," The Historical Journal 54, no. 2 (2011), 555. DOI: 10.1017/S0018246X11000124

${ }^{11}$ Ibid; Dirk A. Moses, "Revisiting a Founding Assumption of Genocide Studies," Genocide Studies and Prevention 6, no. 3 (2011), 289, accessed January 20, 2019, http://scholarcommons.usf.edu/gsp/vol6/iss3/10; Dirk A. Moses, "Toward a Theory of Critical Genocide Studies," Online Encyclopedia of Mass Violence, [online], Mass Violence and Resistance Research Network, Sciences Po, April 18, 2008, accessed, January 20, 2019, https://www.sciencespo.fr/mass-violencewar-massacre-resistance/en/document/toward-theory-critical-genocide-studies.

${ }^{12}$ Moses, Revisiting a Founding Assumption, 292-293.

${ }^{13}$ Mahmood Mamdani, “The Politics of Naming: Genocide, Civil War, Insurgency," London Review of Books 29, no. 5 (March 8, 2007), 5-8, accessed March 12, 2019, https://www.lrb.co.uk/v29/n05/mahmood-mamdani/the-politics-ofnaming-genocide-civil-war-insurgency.

${ }^{14}$ Douglas Irvin-Erickson, “Genocide Discourses: American and Russian Strategic Narratives of Conflict in Iraq and Ukraine, Politics and Governance 5, no.3 (2017), 133. DOI: 10.17645/pag.v5i3.1015. On hidden genocides and, particularly colonial genocides, see, Alexander L. Hinton, et al, eds., Hidden Genocides (New York: Rutgers University Press, 2014).

${ }^{15}$ Dirk A. Moses, “Why the Discipline of "Genocide Studies" has Trouble Explaining how Genocides End," The Social Science Research Council, accessed January 20, 2019, http://howgenocidesend.ssrc.org/Moses.
} 
of the perpetrator group and the victim group are pervasive discourses around contemporary cases of mass violence. Further still, narratives encompassing genocide framings can operate to label the perpetrator social group as collectively evil, while the victim group is moralized collectively as good. ${ }^{16}$ The logic of genocide labeling processes encompassing these binaries is, therefore, largely for the purpose of generating a specific course of political action to prevent or mitigate genocidal violence, namely, interventionism ${ }^{17}$ It was this course of action that was ultimately the desired end of the advocacy campaigning on the violence in Darfur through the Save Darfur movement. ${ }^{18}$ The application of the genocide descriptor uncritically by those associated with the campaign along with scholar-practitioners and journalists reduced the Darfur conflict theatre and complex politics of violence to a "primordial struggle"19 between two monolithic identity groups with 'Arabs' occupying the role of perpetrator and collectively "demonized" and 'Africans' occupying the role of victim..$^{20}$ As a consequence, this framing inaccurately portrayed social groups in Darfur (as would be the case elsewhere) as unified collectives and ignored the shifting and diverse roles individuals from within these social identity groups had in relation to violence. Moreover, as Mamdani further highlights, it also critically served to obscure the contentious politics around belonging in Sudan and claims embedded in struggles over how meaning is made of these identities. ${ }^{21}$ Beyond Darfur, Irvin-Erickson has observed similar discursive frames employed in debates in the United States over the genocidal violence of Islamic State and how to respond. ${ }^{22}$ Taken together, labeling violence as genocide, therefore, is not an analytically neutral act, but rather takes a position in a particular conflict suggesting discourses on genocide can play a generative role in conflict not only from advocating military interventionism, ${ }^{23}$ but for how they have the potential to obscure the micropolitics of violence, or, indeed, an entirely different violence trajectory (see Purdeková, this issue).

Reverberations of simplistic perpetrator/victim binaries embedded in such framings of genocidal violence are not bound by time but can have broader peacetime implications. The legacy of crude, moralistic binaries embedded in central genocide studies narratives of the Rwandan genocide that resulted from an analytical propensity toward prioritizing the 1994 genocide of the Tutsi, Jones argues, have not merely afforded the Kagame administration political legitimacy. So too have they insulated the government from international pressure over its record of perpetrating past acts of mass violence and current human rights abuses. ${ }^{24}$ Compounding many of these issues, Jones further observes, is a "pervasive sense of shame," felt in Western capitals over international political inaction in $1994 .{ }^{25}$ Elsewhere, in her examination of Rwandan state implemented policies to promote national unity and reconciliation that have been much lauded internationally, Thompson underscores the pervasive reach of state power into the lives of ordinary Rwandans, but also the ways in which these same individuals subtly resist. By doing so, Thompson illustrates a critical disconnect between what reconciliation policies are thought to be achieving on the ground and what is actually transpiring. ${ }^{26}$

\footnotetext{
${ }^{16}$ Irvin-Erickson, Genocide Discourses, 133-135; Mamdani, The Politics of Naming, 5-8.

${ }^{17}$ Ibid.

${ }^{18}$ Don Cheadle \& John Prendergast, The Mission to End Genocide in Darfur and Beyond (New York: Hachette Books, 2007); see also, Eric Reeves, "Sudan: Research, Analysis and Advocacy," accessed May 20, 2019, http://sudanreeves.org.

${ }^{19}$ Irvin-Erickson, Genocide Discourses, 136.

${ }^{20}$ Mamdani, The Politics of Naming, 5-8.

${ }^{21}$ Mamdani, The Politics of Naming, 5-8.

${ }^{22}$ Irvin-Erickson, Genocide Discourses, 135-140.

${ }^{23}$ Ibid., 133-135.

${ }^{24}$ Adam Jones, "The Great Lakes Genocides: Hidden Histories, Hidden Precedents," in Hidden Genocides, ed. Alexander L. Hinton, et al (New York: Rutgers University Press, 2014), 130-131.

${ }^{26}$ Susan Thompson, Whispering Truth to Power: Everyday Resistance to Reconciliation in Postgenocide Rwanda, (Madison: University of Wisconsin Press, 2013).
} 
The Responsibility to Protect

Adopted at the 2005 United Nations World Summit by heads of government and state, the Responsibility to Protect (R2P) is the principle now most invoked in contemporary political discourse, guiding how the international community perceives its commitment and response to large scale violence. ${ }^{27}$ Culminating in the development of the R2P normative framework, the intellectual history of reconceptualizing state sovereignty finds its roots in Africa and, particularly over concerns around mass violence in southern Sudan and Khartoum's unwillingness to act on its responsibilities to its own people. ${ }^{28}$ It was from Francis Deng's concerns here that he and colleagues - Sadikiel Kimaro, Terrence Lyons, Donald Rothchild, and William Zartman - argued for "sovereignty as responsibility." 29 State sovereignty, they argued, entailed obligations whereby it is incumbent on sovereign states to domestically safeguard the welfare of all those living within their territories. ${ }^{30}$ From its foundation in intellectual debates on sovereignty, the R2P norm, thereafter, evolved through the International Commission on Intervention and State Sovereignty in $2005^{31}$ and, later, through the UN Secretary General's report on the application of R2P. ${ }^{32}$ With its evolution came a disaggregation of the notion of responsibility ${ }^{33}$ and a specification of broader categories of violence incumbent upon states to prevent that importantly included genocide ${ }^{34}$ To that effect, not only do individual states have a national responsibility to safeguard their domestic populations from the threat and commission of genocide, crimes against humanity, war crimes, and ethnic cleansing, so too do they have an international responsibility to ensure other sovereign states work to fulfill their domestic obligations to protect their populations under R2P. ${ }^{35}$ Embedded in the normative framework, therefore, is not only the notion of prevention and protection, at least rhetorically, as collaboration, but also as one of responsibility. ${ }^{36}$

The shift in international political discourse from conceiving of mass violence prevention as singularly done through military intervention to a more positive discourse on prevention through a variety of mechanisms (non-militarized and militarized respectively) was much needed. However, the political discourse and application of the R2P framework and, particularly the international element of responsibility in contexts where it is perceived states are reneging on their sovereign responsibilities has drawn sharp criticism. From voices in the global south arguing the imperialist undertones of the framework divide the world between those states whose populations are secure from mass violence and, therefore, concerns around their domestic responsibilities under R2P are of little import, to those states innately incapable of safeguarding against mass violence and their populations requiring external efforts, as a result, to protect them. To the global north where it is argued the discourse around prevention as responsibility is not immune from likely exploitation by powerful states seeking to simultaneously legitimize and detract attention from their interventionist

\footnotetext{
${ }_{27}$ Philip Cunliffe, "Introduction: Critical Perspectives on R2P," Journal of Intervention and Statebuilding, 4, no. 1 (March 2010), 35-37. DOI: 10.1080/17502970903541655

${ }^{28}$ For a clear early articulation of responsibility to protect as applied to Sudan, see, Francis Deng and Larry Minear, Challenges of Famine Relief: Emergency Operations (Washington, DC: Brookings Institution Press, 1992).

${ }^{29}$ Francis Deng, et al, Sovereignty as Responsibility: Conflict Management in Africa (Washington, DC: Brookings Institution Press, 1996).

${ }^{30}$ Ibid., 211.

${ }^{31}$ International Commission on Intervention and State Sovereignty, The Responsibility to Protect: Report of the International Commission on Intervention and State Sovereignty (Ottawa: International Development Research Centre, 2001), 4, accessed March 12, 2019, http://responsibilitytoprotect.org/ICISS\%20Report.pdf.

${ }^{32}$ United Nations, 2005 World Summit Outcome Document, October 24, 2005 (UN Doc. A/RES/60/1), paras, 138-140, accessed March 12, 2019, https://www.un.org/en/development/desa/population/migration/generalassembly/docs/ globalcompact/A RES 60 1.pdf.

${ }^{33}$ International Commission on Intervention and State Sovereignty, The Responsibility to Protect, xi.

${ }^{34}$ United Nations, 2005 World Summit Outcome Document, para 138-140.

${ }^{35}$ International Commission on Intervention and State Sovereignty, The Responsibility to Protect, xi.

${ }^{36}$ For a review of strong advocates for the responsibility to protect, see generally, Sheri Rosenberg, "Responsibility to Protect: A Framework for Prevention," Global Responsibility to Protect 1, no. 4 (2009), 442-477; Louise Arbour, "The Responsibility to Protect as a Duty of Care in International Law and Practice," Review of International Studies 34, no. 3 (2008), 445-458; Gareth Evans, Responsibility to Protect: Ending Mass Atrocity Crimes Once and For All (Washington DC: Brookings Institution Press, 2008).
} 
political exploits abroad. ${ }^{37}$ Others, (see Kuperman, this issue; see Idris Erameh, this issue) have illustrated the devastating consequences of the uncritical application of R2P in complex wartime contexts. Ultimately, the norm of R2P with its prioritization on state driven protection from mass violence somewhat functions to conceal how we understand the nature of peace and, particularly fostering sustainable peace. That is, rather than employing R2P in the pursuit of strengthening state securitization whereby populations are repeatedly protected from mass violence, as IrvinErickson observes, the emphasis must be toward sovereignty as responsibility as embodied in state institutions operating to preserve the safety of those within the territories of states. ${ }^{38}$ This is all the more imperative given how central statal structures have been and will continue to be in the commission of large-scale mass violence, including genocide. ${ }^{39}$

The Drivers of Conflict

Violent conflicts in Africa are largely driven by the same economic, political, and social forces as conflicts elsewhere around the world. Yet, African states are among the newest in the world. We know that poverty and conflict are correlated, and the continent is poor. As eluded to previously, policy, advocacy, and media accounts emphasize various cultural attributes of conflict and mass violence, often relying on long discredited notions of ancient tribal hatreds fueling violence while ignoring the overwhelmingly peaceful interactions among ethnic groups.

The case of the Central African Republic (CAR) and the most recent increase in violence toward the end of 2012 is illustrative not merely for its complexity, but also for the way in which much of the violence has been portrayed as running almost exclusively along religious fault lines. Determining whether the violence in the CAR is religious or not is largely unhelpful as is, in many ways, the uncritical application of monolithic (monotheistic) religious descriptors to sub-state armed elements and movements in the CAR. A simplistic, religiously dichotomous violence narrative of Christians against Muslims obscures how religion, as a key element in the socio-political fabric of the CAR, has long functioned within identity centric narratives over issues of belonging and citizenship. So too can it function to divert attention away from seeking to understanding more critically how religion has, in the case of the CAR and in other African conflict contexts, shaped the dynamics of violence more overtly over time. Conflict de-escalatory and reconciliatory efforts in the case of the CAR are needed to address both the overt and more historically discrete sociopolitical positioning of religion. ${ }^{40}$

In sum, violent conflicts in Africa are at times protracted but what seemed like impossible to resolve civil wars in Liberia and Sierra Leone or the struggles in Mozambique and Angola have ended. Rather than thinking of "African Conflict" as a category containing various discrete forms of political violence, it is more useful to recognize the micro-dynamics within each conflict. By doing so, it becomes possible to analyze the complex socio-economic and political processes through which violence evolves in diverse and varied ways. Without such an understanding of the nature of conflicts in African contexts, analyses - academic or otherwise - will be stymied by two-dimensional understandings of what is evolving on the ground. As a consequence, the frameworks and policies adopted by various actors may do anything but mitigate conflict and large-scale violence.

\footnotetext{
${ }^{37}$ See, for example, Mahmood Mamdani, "Responsibility to Protect or Right to Punish?" in Critical Perspectives on the Responsibility to Protect: Interrogating Theory and Practice, ed. Philip Cunliffe (London: Routledge, 2011), 125-138; on the likely manipulation of R2P, see, Douglas Irvin-Erickson, "Protection from Whom? Tensions, Contradictions, and Potential in the Responsibility to Protect," in Rethinking Security in the Twenty-First Century, ed. Edwin Daniel Jacob (New York: Palgrave Macmillan, 2017), 105-123.

${ }^{38}$ Irvin-Erickson, Protection from Whom, 117-118.

${ }^{39}$ Ibid., 121.

${ }^{40}$ For the most comprehensive English language volume of the dynamics of violence in the Central African Republic see, Tatiana Carayannis and Louisa Lombard, eds., Making Sense of the Central African Republic (London: Zed Books, 2015); on religion and wartime violence in the CAR, see, Laura C. Collins, "Guns and Prayers: Religious Organisations and Wartime Violence in the Central African Republic," (PhD diss., George Mason University, forthcoming).
} 


\section{Rethinking Concepts, Deepening Scholarship}

This special issue, "Rethinking Genocide, Mass Atrocities, and Political Violence in Africa: New Directions, New Inquiries, and Global Perspectives" represents an attempt to critically investigate the conceptual labels used to make meaning of conflicts across Africa. In doing so, this special issue does not start from a position that assumes one form of conflict is inherent to the African continent or that conflicts throughout Africa are uniform or unchanging. Nor is it understood that the continent is uniquely inclined toward outbreaks of violent conflict or that when there is an outbreak of conflict it is markedly different from how conflict and violence unfold elsewhere. ${ }^{41}$ Rather, it is premised on an understanding that conflict and violence in Africa are often (and perhaps disproportionally) conceptualized through the prism of terms as "genocide," "civil war," "mass atrocities," "religious violence," "ethnic violence," or "terrorism." These frames serve to focus our analytical gaze on society-wide or national level events and processes but conceal both the fine-grain local dynamics of conflicts as well as the role of regional competitions, and transnational dynamics facilitated by porous borders or diaspora communities. Within this context, the special issue asks whether the traditional paradigms of understanding violence and peace, and how we seek to prevent, mitigate, and resolve violence are still relevant to understanding conflict in African contexts.

To answer this call, the papers included in this special issue examine a variety of cases throughout the African continent from Libya to Burundi and have been written from different epistemological approaches and disciplinary backgrounds. Many of the contributions seek not merely to critically analyze the application and applicability of conflict frames employed by international observers and national governments, but also to examine the conceptual, theoretical, and practical consequences of conflict framing on the politics of violence, conflict prevention and mitigation, and peacebuilding efforts. Moreover, from negotiating peace to considerations of amnesty, others critically engage these conventional conflict resolution approaches to end violence and secure peace.

In her contribution opening this special issue, Andrea Purdeková seeks to further problematize the notion of "preventive framing" and, specifically employing the genocide label as a mechanism for prevention. Purdeková's paper, “\#StopThisMovie and the Pitfalls of Mass Atrocity Prevention: Framing of Violence and Anticipation of Escalation in Burundi's Crisis (2015-2017)," draws on a wealth of data to trace how the recent dynamics of violence in Burundi and its escalation were characterized for broad consumption using the genocide descriptor - explicitly and implicitly - for the purposes of persuading, effecting, and ultimately to prompt interventionist preventive action. Framed by an understanding of labeling is an essential element of conflict rather than a phenomenon that operates above the conflict fray, Purdeková examines the unspoken and inadvertent consequences of raising the specter of likely genocide in Burundi. Though activists may lament the ultimate ineffectiveness of deploying the genocide frame to garner swift and decisive regional or international preventive action, it was effective, Purdeková argues, in obscuring pertinent variables undergirding violence and instability in Burundi, and the more likely and pressing escalation trajectory toward civil war. Specifically, analyses tended toward drawing similarities uncritically between Rwanda and Burundi's pasts as determining the only likely trajectory to be genocide. Consequently, while invoking the genocide frame overemphasized the role of ethnicity, failure - at a result - to imagine or recognize an alternative possible trajectory for the crisis in Burundi, Purdeková observes, was perhaps the most detrimental unintended consequences of how the conflict was framed. Rather than mitigate abuses and deepening repression, determinations of impending genocide facilitated a political standoff in which, Purdekovà argues, violence became more hidden and organized. Moreover, a preoccupation with preventing an impending genocide, in turn, prevented steps toward broader considerations of a political solution to the violence. Compounding this was the way in which these uncritical determinations of the evolution of the crisis contributed to the government turning inward and distancing itself from international influence.

If Purdeková's paper serves as a critical entry point to broader considerations of the unintended consequences embedded in the preventive agenda, Alan Kuperman's contribution takes this

\footnotetext{
${ }^{41}$ See, Straus, Wars Do End, 187.
} 
theme one step further by testing the moral hazard of humanitarian intervention hypothesis in the Libyan case. In his, "Did R2P Foster War in Libya," Kuperman examines the 2011 Libyan uprising to explicate whether the decision to instigate, escalate, or sustain the rebellion was done based on a belief held by those involved that a counteroffensive launched by the Qaddafi regime would provoke an external humanitarian military intervention that would, in turn, advance their revolutionary agenda. By tracing of the chronology of events and decisions made around the instigation and perpetuation of the Libyan rebellion, Kuperman provides an alternative reading of its onset. For Kuperman, the rebellion unfolded from the east and, particularly from preplanned violence perpetrated by Islamist militants in the region. This violence, Kuperman argues, co-occurred with protest events in Benghazi rather than emerging in their wake as conventional narrations suggest. Concurrently, Kuperman draws upon new documentary sources to reveal the positions, interests, and ultimately illustrates the shifting strategic calculus of the rebel forces and, particularly their leadership from the point of initiating rebellion to deciding to continue it. Taken together, while it was self-belief alone in their ability to triumph over the Qaddafi regime that propelled militants to initiate rebellion, external intervention was increasingly understood by their leadership as essential for not merely the continuation of their struggle, but to facilitate an eventual victory. Strong intimations in support of humanitarian military intervention given by NATO members heightened the belief among the rebels that such assistance was not only a possibility, but forthcoming. Rebel leadership, Kuperman further suggests, also attempted to actively court such assistance by overstating the state-sponsored threats to civilians. With the eventual arrival of the NATO-led intervention, the otherwise short-lived rebellion continued for several months. Yet, violence escalated and the civilians the humanitarian military intervention had ostensibly been launched to protect were subjected to widespread and persistent violence. The Libyan case, Kuperman argues, is yet further evidence of the need to critically assess how R2P is approached in order to grapple more seriously with moral hazard. Atrocity prevention, Kuperman concludes, demands intervention strategies be informed and controlled.

Interwoven throughout the contributions offered by Purdeková and Kuperman is a commitment to highlighting the complexity of the African wartime environment; a complexity that is often at best obscured and at worse dismissed in favor of a tendency toward reductionist and misleading portrayals of conflict dynamics, actors, and their interests much to the detriment of civilian protection, mitigating violence, and fostering paths toward a cessation of hostilities and peace. In doing so, they expose to varying degrees how the local matters and select actors in conflicts are not passive recipients of frames employed by external agents in understanding their context. It is not that Africans fight over different things than those in other parts of the world. But deeply embedded assumptions generate analytical conclusions that often overlook political dynamics and highlight identity, hence making genocide appear more likely.

Building on this, Nicolas Idris Erameh, in "The Practices, Pitfalls, and Prospects of the Responsibility to Protect (RtoP) in Africa," argues for more importance to be given to understanding localized conflict dynamics and how R2P is understood locally in contexts where the R2P normative framework is applied, and particularly prior to engaging in militarized forms of intervention encompassed under the third pillar of the framework. Efforts, Idris Erameh argues, are required to rethink the notion of last resort pertaining to militarized interventionism in conjunction with more active and tangible engagement in the pursuit of political and diplomatic solutions for conflict throughout the continent. The importance, Idris Erameh suggests, of developing more contextually attuned understandings of conflict lies in the ability, thereafter, to shift discourse and action on R2P in Africa from militarized to non-militarized mechanisms for prevention. Concurrently, Idris Erameh contents the prospects of R2P in Africa demand a re-examination of what unfolds during the interactions between those who intervene and those who are intervened upon. Specifically, renewed considerations of the varying power dynamics between these parties are vital. In consideration of the enduring issues of power embedded in discourses surrounding R2P and, particularly at the level of practice, Idris Erameh not merely underscores the relative and continued marginalization of African states in vital decision-making processes and measures taken under the auspice of R2P, but also the manner in which past intervening states have appeared unencumbered by the spirit of the framework. One possible solution, he suggests, lies in critically engaging the 
notion of "responsibility while protecting" and its associated elements of proportionality on the part of states intervening militarily, on the one hand, and offsetting the implications of external intervention, on the other.

Along with considerations of genocide framing and the responsibility to protect, other contributors to this special issue engage the framing politics of terrorism. Michael Loadenthal, in "Othering Terrorism: A Rhetorical Strategy of Strategic Labeling," turns our attention to rhetorical processes of othering as captured through an examination of print and film media coverage. The analysis draws upon the film, Black Hawk Down, media reports of Boko Haram in Nigeria, non-state media productions generated by actors such as Al-Shabab in Somalia, and rightist violence. Loadenthal illustrates how framings of political violence and, particularly 'terrorism,' acts of 'terroristic' violence, and whom is considered to be a 'terrorist,' vary sharply from those surrounding notions of 'extremism' and 'extremists.' Specifically, Loadenthal contends that through the production and reproduction of discourse, notions of 'terrorism' are constructed in such a way whereby they are deeply tied to notions of foreign, non-white and, non-western identities. Conversely, white, Christian actors operate outside of these discursive frames of othering, and rightist violence committed by these actors are omitted from 'terrorism' determinations. Framing violence as 'terroristic,' Loadenthal illustrates, has little to do with the tactics employed by sub-state entities. Loadenthal then connects these observations over how political violence and, particularly terrorism is framed to broader issues of denials of political legitimacy and empathy. The descriptor 'terrorist' applied to brown and black bodies lends legitimacy to state-enacted mass violence while the lives of persons marked as terrorists are deemed unmournable and ultimately disposable. Loadenthal concludes that these racialized discourses of otherness will continue to be used to justify state violence until we are able to extend dignity, legitimacy, and empathy to armed resisters around the world.

Turning to the Nigerian case specifically, Chinonye Alma Outonye's contribution, “The Fight for Language: An Exploration of the Nigerian State's Response to Protest Groups in Southeastern Nigeria," examines how a state's use of language and, specifically categorizing certain forms of collective action subversive, acts as a strategy through which to dominate and discredit certain groups' grievances within wider public discourse. The Nigerian state, Outonye argues, cloak their rational for deploying direct violence against resurgent pro-Biafra movements in security imperatives and, particularly arguments couched in their legitimate right to use force to defend against perceived threats to the territorial integrity of the state. Within this framework, linguistic determinations of these movements as 'extremists' and 'terrorists' serve to position them and their demands as irrational and illegitimate. Nigerian state-sponsored violence in Biafra, thereafter, is at once rationalized and normalized. This labeling strategy not merely shapes how these protest groups experience state violence, but, as Outonye contends, such determinations also function to disconnect these movements from their local context and, in turn, the broader issues undergirding their emergence. Further still, given the perceived illegitimacy of these movements, such labels work to obscure a range of possible alternative mechanisms, including dialogue in preference for violence to address pro-Biafra movements. Taken together, Outonye critically illustrates how the strategic application of these labels by the Nigerian state not only obfuscates the legacy of the Nigeria-Biafra war on the Eastern region, including persistent marginalization and discrimination, but the entrenched lack of addressing the history of the war. By underscoring the importance of bringing Nigeria's past into conversation with understanding the present, Outonye provides a deeper understanding of the intricacies of the contemporary Nigeria landscape, which are hidden behind tactics of dismissal and violence employed by the state. The latter of which serves to both deepen tensions and feeds the central freedom and recognition by secession narrative of these movements.

Moving to considerations of how peace is approached, Nathaniel Dominic Danjibo and Owonikoko Babajide Saheed's contribution, "Buying Peace or Building Peace: Rethinking Non-Coercive Approaches to the Management of Non-state Armed Groups Involved in Mass Atrocities," examines the contentious issue of amnesty in conflict contexts. Drawing upon the case of the Nigerian state-sponsored amnesty program implemented in the Niger Delta, Danjibo and Owonikoko illustrate how the use of this particular strategy to address the existence and 
activities of non-state armed actors, and their associated violence served as little more than a mechanism to placate violent agents. Much of the failure of the amnesty program, the authors contend, can be attributed to the way in which this approach was not embedded in a larger process toward peace embarked upon by the state in conjunction with armed nonstate actors in the Delta. Specifically, despite the inclusion of a disarmament, demobilization, and reintegration component, there was neither an initiation of dialogue nor broader considerations of either the structural violence propelling instability in the Delta, or the legacy of the direct violence perpetrated by both the state and non-state armed groups. Bringing the lessons of granting amnesty in the Niger Delta into conversation with the conflict context in North East Nigeria, Danjibo and Owonikoko argue an amnesty provision alone would be inadequate to bring an end to Boko Haram violence. Moreover, as the authors highlight, questions persist as to whether the group's leadership would be receptive to amnesty. Rather, there is a need for more contextually attuned, non-violent strategies to building peace in the region. This, for the authors, is part of a larger imperative to integrate peacebuilding approaches into atrocity prevention efforts and negotiating peace - that is, there is a continued need for holistic peacebuilding to promote sustainable peace in Nigeria and elsewhere on the continent.

From Nigeria to the Great Lakes region, Jonathan Belof and Samantha Lakin in, "Peace and Compromise, Idealism and Constraint: The Case of the Arusha Peace Accords in Rwanda and Burundi," draw on data collected from elite interviews to illustrate the complexities of negotiating peace, charting not only the enduring consequences of these processes, but their unintended effects. Rather than facilitate peace, the Rwandan Arusha Accords failed to counteract the civil war continuing and had the unintended effect of affording the political space and time for genocide preparation. It was this, Belof and Lakin argue, that had the further unintended effect of an RPFled retightening of the domestic political arena in the aftermath of the 1994 genocide to prevent a resurgence of extremist views. A move that has effectively eviscerated competitive party-politics in Rwanda, which persists today. Beyond domestic politics, Belof and Lakin illustrate how the experience of the failed Arusha Accords and genocide have broader implications for how Rwanda engages in international politics, and particularly their involvement in regional peacekeeping missions. Presenting a somewhat alternative understanding, the authors suggest, Rwandan state motivation is in part driven by their own experience with genocide. In Burundi, by foregrounding the composition of the negotiation process and, particularly the actors involved, they illustrate how parties engaged in negotiation processes and, thereafter, are at once structurally and behaviorally dynamic, and politically strategic. As such, in spite of the comprehensive power-sharing framework that emerged based on multi-ethnic political inclusion and initial multi-ethnic posturing, ethnicity, Belof and Lakin argue, continued to be salient for power holders and, particularly the ruling party in the mid 2000s. The continued prevalence of identity-based politics gradually permitted abuses of power and a re-emergence of varying forms of violence. Compounding this issue, the authors suggest, has been repeated institutional failure and a failure to enforce and oversee the agreement. Despite the Arusha Accords in Burundi having successfully ended the civil war, they have ultimately failed to avert a continuation of direct violence and address more ingrained structural violence.

Taken together, a major theme emanating from the contributing discussions is the way in which some of the frames used to understand violence and contribute to peace may in fact facilitate violence or a violent response to conflict. To that effect, the contributors of this issue form a timely and important collective voice in the advancement of the critical agenda around how we conceive of and thereafter seek to resolve violent conflict in Africa and elsewhere.

Laura Collins

\section{Bibliography}

Arbour, Louise. “The Responsibility to Protect as a Duty of Care in International Law and Practice." Review of International Studies 34, no. 3 (2008), 445-458. DOI: 10.1017/s0260210508008115

Carayannis, Tatiana and Louisa Lombard, eds. Making Sense of the Central African Republic. London: Zed Books, 2015. DOI: 10.1017/s0001972016000899 
Cheadle, Don and John Prendergast. The Mission to End Genocide in Darfur and Beyond. New York: Hachette Books, 2007.

Collins, Laura C. "Guns and Prayers: Religious Organisations and Wartime Violence in the Central African Republic." PhD diss., George Mason University, forthcoming.

Cunliffe, Philip. "Introduction: Critical Perspectives on R2P." Journal of Intervention and Statebuilding 4, no. 1 (March 2010), 35-37. Accessed March 20, 2019. DOI: 10.1080/17502970903541655

Cunningham, David E. Barriers to Peace in Civil Wars. Cambridge, UK: Cambridge University Press, 2011.

Deng, Francis and Larry Minear. Challenges of Famine Relief: Emergency Operations. Washington, DC: Brookings Institution Press, 1992.

Deng, Francis, Sakikiel Kimaro, Terrence Lyons, Donald Rothchild, and William Zartman. Sovereignty as Responsibility: Conflict Management in Africa. Washington, DC: Brookings Institution Press, 1996.

Evans, Gareth. Responsibility to Protect: Ending Mass Atrocity Crimes Once and For All. Washington, DC: Brookings Institution Press, 2008.

"Farmer-pastoralist conflicts cause more deaths than Boko Haram." The Nordic Africa Institute, June 26, 2017. Accessed April 12, 2019. https://nai.uu.se/news/articles/2017/06/26/113908/index. xml.

Hinton, Alexander L., Thomas La Pointe, and Douglas Irvin-Erickson, eds. Hidden Genocides. New York: Rutgers University Press, 2014.

International Commission on Intervention and State Sovereignty. The Responsibility to Protect: Report of the International Commission on Intervention and State Sovereignty. Ottawa: International Development Research Centre, 2001. Accessed March 12, 2019. http:// responsibilitytoprotect.org/ICISS\%20Report.pdf.

Irvin-Erickson, Douglas. "Genocide Discourses: American and Russian Strategic Narratives of Conflict in Iraq and Ukraine." Politics and Governance 5, no. 3 (2017), 130-145. Accessed March 12, 2019. DOI: $10.17645 /$ pag.v5i3.1015

"Protection from Whom? Tensions, Contradictions, and Potential in the Responsibility to Protect." In Rethinking Security in the Twenty-First Century, edited by Edwin Daniel Jacob, 105-123. New York: Palgrave Macmillan, 2017. DOI: 10.1057/978-1-137-52542-0 8

Jones, Adam. "The Great Lakes Genocides: Hidden Histories, Hidden Precendents." In Hidden Genocides, edited by Alexander L. Hinton, Thomas La Pointe and Douglas Irvin-Erickson, 129-148. New York: Rutgers University Press, 2014.

Kalyvas, Stathis. The Logic of Violence in Civil War. New York: Cambridge University Press, 2006.

Marks, Zoe, Erica Chenoweth, and Jike Okeke. "How Protest Movements Are Succeeding Where Even Global Arrest Warrants Can't." Foreign Affairs, April 25, 2019. Accessed April 26, 2019. https://www.foreignaffairs.com/articles/africa/2019-04-25/people-power-rising-africa.

Mamdani, Mahmood. "The Politics of Naming: Genocide, Civil War, Insurgency." London Review of Books 29, no. 5 (March 8, 2007), 5-8. Accessed March 12, 2019. https://www.lrb.co.uk/v29/ n05/mahmood-mamdani/the-politics-of-naming-genocide-civil-war-insurgency.

---------. "Responsibility to Protect or Right to Punish?" In Critical Perspectives on the Responsibility to Protect: Interrogating Theory and Practice, edited by Philip Cunliffe, 125-138. London: Routledge, 2011. DOI: 10.4324/9780203834299

Moses, Dirk A. "Toward a Theory of Critical Genocide Studies." Online Encyclopedia of Mass Violence, [online], Mass Violence and Resistance - Research Network, Sciences Po, April 18, 2008. Accessed January 20, 2019. https://www.sciencespo.fr/mass-violence-war-massacreresistance/en/document/toward-theory-critical-genocide-studies.

"Paranoia and Partisanship: Genocide Studies, Holocaust Historiography, and the 'Apocalyptic Conjecture'." The Historical Journal 54, no. 2 (2011), 553-583. Accessed January 20, 2019. DOI: 10.1017/S0018246X11000124

. "Revisiting a Founding Assumption of Genocide Studies." Genocide Studies and Prevention 6, no. 3 (2011), 287-300. Accessed January 20, 2019. http://scholarcommons.usf.edu/gsp/ vol6/iss3/10. 
--------. "Why the Discipline of 'Genocide Studies' has Trouble Explaining how Genocides End." The Social Science Research Council. Accessed January 20, 2019. http://howgenocidesend. ssrc.org/Moses.

Nnoko-Mewanu, Juliana. "Farmer-Herder Conflicts on the Rise in Africa," Human Rights Watch, August 6, 2018. Accessed April 12, 2019. https://www.hrw.org/news/2018/08/06/farmerherder-conflicts-rise-africa.

Reeves, Eric. "Sudan: Research, Analysis and Advocacy." Accessed May 20, 2019. http:// sudanreeves.org.

Rosenberg, Sheri. "Responsibility to Protect: A framework for Prevention." Global Responsibility to Protect 1, no. 4 (2009), 442-477.

Shaw, Martin. Genocide and international Relations: Changing Patterns in the Upheavals of the Late Modern World. Cambridge, UK: Cambridge University Press, 2013.

. What is Genocide? Cambridge, UK: Polity, 2007.

Straus, Scott. "Wars Do End! Changing Patterns of Political Violence in Sub-Saharan Africa." African Affairs 111, no. 443 (2012), 179-201. Accessed December 12, 2018. DOI: 10.1093/afratf/ads015 Making and Unmaking Nations: War, Leadership, and Genocide in Modern Africa New York: Cornell University Press, 2015.

Thompson, Susan. Whispering Truth to Power: Everyday Resistance to Reconciliation in Postgenocide Rwanda. Madison: University of Wisconsin Press, 2013.

United Nations. 2005 World Summit Outcome Document. October 24, 2005. UN Doc. A/RES/60/1. Accessed March 12, 2019. https://www.un.org/en/development/desa/population/ migration/generalassembly/docs/globalcompact/A RES 60 1.pdf.

Verdeja, Ernesto. "On Situating the Study of Genocide within Political Violence." Genocide Studies and Prevention 7, no. 1 (2012), 81-88. Accessed March 12, 2019. DOI: 10.3138/gsp.7.1.81

Von Soest, Christian and Alexander De Juan. "Dealing with New Security Threats in Africa." GIGI Focus Afrika, 2018. Hamburg: GIGA German Institute of Global Area Studies - LeibnizInstitute für Globale und Regionale Studien, Institute für Afrika-Studien. Accessed December 12, 2018. https://www.ssoar.info/ssoar/bitstream/handle/document/57825/ ssoar-2018-soest et al-Dealing with New Security Threats.pdf?sequence=1\&isAllowed $=y \&$ Inkname=ssoar-2018-soest et al-Dealing with New Security Threats.pdf.

Walter, Barbara F. "Why Bad Governance Leads to Repeat Civil War." Journal of Conflict Resolution 59, no. 7 (2015), 1242-1272. Accessed December 12, 2018. DOI: 10.1177/0022002714528006

Williams, Paul D. "Continuity and Change in War and Conflict in Africa." Prism 6, no. 4 (2017), 3245. Accessed December 12, 2019. https://www.jstor.org/stable/10.2307/26470480. 